\title{
The use of Lespedeza cuneata for natural control of gastrointestinal nematodes in Merino sheep
}

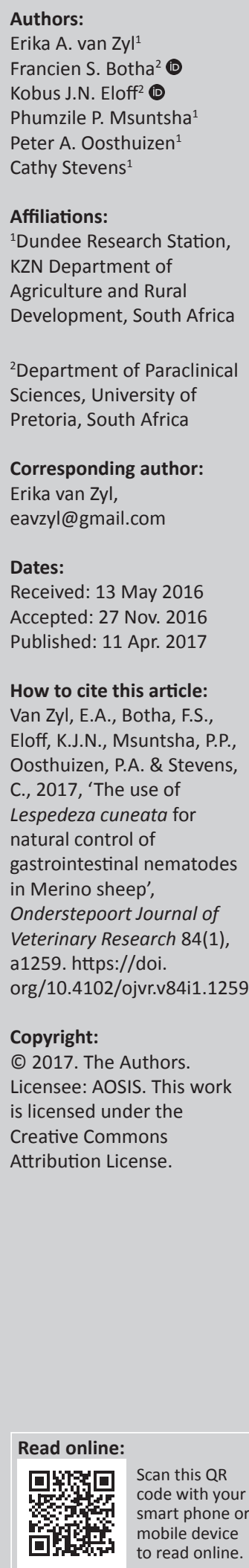

Lespedeza cuneata (poorman's lucerne; sericea lespedeza), a tannin-rich perennial legume, was offered as hay to dry Merino ewes in a confined feeding experiment to evaluate the effect on the level of gastrointestinal parasite infection in sheep. Medicago sativa (a low tannin containing perennial legume) was used as the control treatment. Parameters faecal egg count (FEC), FAMACHA $^{\odot}$ scores and rectal temperatures were used. FECs were substantially lower $(p=$ $0.05)$ in the Lespedeza group after 35 days, together with a trend of higher rectal temperatures, compared with the Medicago group. Although non-significant $(p>0.05)$, the higher rectal temperatures suggested a lower level of anaemia in the sheep on the Lespedeza ration and, therefore, a lower parasite-worm burden. However, FAMACHA ${ }^{\odot}$ scores showed no significant $(p>0.05)$ differences between treatments despite the differences in FEC that were recorded, indicating that host homeostasis was possibly mediated by improved nutrition as a result of the high protein content of both experimental diets.

\section{Introduction}

The existence of livestock is closely bound to that of parasites (Villalba et al. 2014). Increased concentrations of livestock and monoculture foraging have enhanced gastrointestinal parasite populations to such a level that livestock production has, to a large extent, become dependent on anthelmintic chemotherapy. The extensive use of these synthetic anthelmintics to control gastrointestinal nematode (GIN) infections, driven by frequency of treatment and underdosing of animals, has resulted in the development of widespread nematode resistance to chemical anthelmintics (Besier \& Love 2003; Greef, Karrison \& Schlink 2014; Morgan et al. 2013; Preston et al. 2014; Taylor, Hunt \& Goodyear 2002). The most important strongylid nematodes in the tropics and subtropics that cause severe economic losses in sheep farming is Haemonchus contortus (Adamu 2012; Adamu, Naidoo \& Eloff 2013; Vatta \& Lindberg 2006), which showed resistance in the benzimidazole group for the first time in South Africa in 1975 (Berger 1975). Since then, the levels of resistance in South Africa are among the highest in the world (Van Wyk et al. 1999; Vatta \& Lindberg 2006).

The increased drug resistance of parasites to modern anthelmintics, together with the increased public awareness of drug residues in animal products, motivated the search for alternative endoparasite control strategies in small stock. Research has identified promising alternative anthelmintics in several well-known pasture species, the so-called bioactive forages, such as chicory (Athanasiadou et al. 2007; Foster, Cassida \& Turner 2011; Heckendorn 2007), sainfoin (Heckendorn 2007; Hoste et al. 2014), sulla (Niezen et al. 1995, 1998) and sericea lespedeza (Lange et al. 2006; Moore et al. 2008; Shaik et al. 2006). These pastures have a tremendous advantage over many other plants with anthelmintic activities, because they are already established as planted pastures and available on farms for direct consumption by animals as grazing or as preserved feed as hay.

Of specific importance are the tanniferous forages, where indications are that condensed tannins (CTs) play a cardinal role in the anthelmintic activities. Generally, tannins will defend the plant against utilisation by lowering the palatability and negatively influencing digestion. The slowdown in digestion caused by tannins can, in turn, also lower intake because of gut fill (Barry \& McNabb 1999; Hovarth 1981; Rahmann \& Seip 2007; Reed et al. 1982; Shimada 2006).

These negative effects are generally associated with forages that contain high CT concentrations of above $55 \mathrm{~g} \mathrm{CT} \mathrm{kg}^{-1}$ dry matter (DM) (Min \& Hart 2003). Diets with moderate concentrations of CT $\left(20 \mathrm{~g} \mathrm{CT} \mathrm{kg}^{-1}-40 \mathrm{~g} \mathrm{CT} \mathrm{kg}^{-1} \mathrm{DM}\right)$ may lead to improved protein nutrition when tannins complex with plant proteins, resulting in increased protein assimilation by safeguarding some proteins 
past the rumen to the rest of the intestines, instead of being lost through secretion (Hoste et al. 2006; Min \& Hart 2003).

CTs may thus have an indirect effect on GIN, by replenishing the extensive endogenous protein losses encountered in the abomasum and small intestine of the host during GIN parasitism, thus enhancing immunity or improving host homeostasis (Bown, Poppi \& Sykes 1991; Hoste et al. 2006; Min \& Hart 2003; Niezen et al. 2002).

The mechanism of activity of direct effects of tannins on parasites is less clear than the indirect effects. Electron microscope investigations showed cuticular changes after contact with tannins, which may inhibit or delay the exsheathment of the $\mathrm{L}_{3}$ stage after indigestion by the host (Hoste et al. 2006). A hypothesis was put forward that CT bonding takes place with the proline- and hydroxyprolinerich cuticle that covers the body and lines certain parts of the digestive tract and reproductive system of the nematode (Hoste, Torres-Acosta \& Aguilar-Caballero 2007).

Several workers reported repressed female nematode reproductive activity as another direct effect of CT on GIN, which explained the decrease in faecal egg count (FEC) measured in several trials where feeding experiments were conducted with tannin-rich forages (Ahmed, Laing \& Nsahlai 2010; Heckendorn 2007; Lange et al. 2006; Min \& Hart 2003; Min et al. 2005; Niezen et al. 1998, 2002; Shaik et al. 2004, 2006). However, research done on goats by Shaik et al. (2006) showed that a CT diet had highly significant $(p<0.001)$ effects on reducing the numbers of adult nematodes in both the abomasum and small intestines, and that female nematodes were more affected.

Lespedeza cuneata, also known as sericea lespedeza or poorman's lucerne, is a CT-containing pasture that has anthelmintic properties (Ahmed et al. 2010; Lange et al. 2006; Min \& Hart 2003; Min et al. 2005; Shaik et al. 2004, 2006; Terrill et al. 1989). Significant outcomes were measured regarding a reduced FEC and increased packed cell volume, but insufficient on-farm implementation strategies were recommended (Burke et al. 2011; Gujja et al. 2013; Kommuru et al. 2014; Shaik et al. 2004, 2006; Terrill et al. 2007). Many of the studies were done on goats.

An advantage of L. cuneata, above several other plants with confirmed anthelmintic properties, is that it is already a commercially established pasture with seed available, is relatively drought resistant and is adaptable to low fertility soils (Dannhauser 2002). Being a legume, it has nitrogenfixing abilities, which make it a low input pasture. The main objective of the current investigation was to determine the effects of feeding L. cuneata leaf hay on the level of an established gastrointestinal parasite infection in Merino sheep as measured by FEC. The second objective was to investigate whether changes in the level of GIN infection, if any, could be detected by changes in rectal temperature and FAMACHA $^{\odot}$ scoring as an indication of anaemia. Anaemia, as a result of a loss of haemoglobin due to parasitism, is associated with low body temperature caused by a restricted oxygen and iron supply to cells in the body, which in turn, interferes with the ability of the body to regulate its temperature.

Medicago sativa (commonly known as lucerne or alfalfa), a perennial legume pasture, was used as the control forage. It has a low CT content and lacks anthelmintic properties and is often used as contrasting forage to high-tannin forages in parasite-forage studies (Valderrábano, Calvete \& Uriarte 2010).

\section{Materials and methods Experimental animals and design}

A confinement feeding trial was conducted with dry, nonpregnant Merino ewes at the Dundee Research Station, KwaZulu-Natal (KZN) Department of Agriculture and Rural Development, South Africa. The sheep were housed in covered barns with open sides and concrete flooring in pens, each covering an area of $24 \mathrm{~m}^{2}$. The pens had similar temperature and sunlight conditions.

The ewes were grazed on rain-fed Nile grass (Acroceras macrum) pasture prior to the commencement of the feeding trial to acquire a low-level GIN infection. Weekly FEC, expressed as eggs per gram (EPG) of individual sheep, verified their GIN infection status. Sufficient levels of infection (mean $\pm 3000 \mathrm{EPG}$ ) were reached after 35 days, and no trickle infection with parasite larvae was needed to boost the level of infection.

Animals $(n=14)$ were then ranked according to their FEC status and assigned to one of two treatment groups. Each treatment was replicated twice. The ewes in each treatment were then allocated to two pens with either three or four sheep in each pen. The pens were, for the duration of the trial, carefully cleaned each day to prevent GIN reinfection.

All husbandry practices and experimental procedures were approved by the applicable authorities. The animals were on a salvaged deworming protocol, that is, deworming with an effective chemical dewormer. This was done using an FEC reduction test prior to the trial. Treatment would take place if the FEC in an individual sheep exceeded a level of 6000 EPG over two consecutive weeks. No animals required salvage deworming throughout the study.

\section{Experimental diets}

The experimental diets were:

- Lespedeza cuneata hay (L group).

- Medicago sativa hay (M group).

The L. cuneata material was obtained from hay made from a pure L. cuneata pasture at Dundee Research Station. The $M$. sativa hay for the trial was brought in from a local commercial producer. 
Sheep are selective grazers, and it was observed that sheep selectively graze or 'browse' L. cuneata, selecting the leaves and avoiding the stems. Therefore, in the experiment, only the leaf part of the hay was used. Stems were removed semimechanically.

Random samples from the forages were taken for feed analysis. Samples were milled through a 2-mm sieve and sent for full feed chemical analysis according to methods described by De Figueiredo and Thurtell (1998), which are based on the Van Soest's (1965) methods. The analyses were done at the Cedara Feed Laboratory of the KZN Department of Agriculture and Rural Development. The results of these analyses were used to nutritionally balance the rations. The Lespedeza ration had to be supplemented and consisted of $80 \%$ L. cuneata leaves, $12 \%$ high protein concentrates and $8 \%$ molasses meal (molasses meal from Molatek: protein = $40 \mathrm{~g} \mathrm{~kg}^{-1}$; metabolisable energy $=105 \mathrm{MJ} \mathrm{kg}^{-1}$ ). The ration of the $\mathrm{M}$ group consisted only of $M$. sativa hay.

For the CT analysis, a random sample was collected from the harvested L. cuneata forage material and air-dried in the shade. Samples were divided by hand into stem and leaf samples for reasons discussed above. These samples were analysed for tannin content by the Cedara Feed Laboratory, according to a method described by Reed et al. (1982) and Waterman and Mole (1994). The CTs were extracted from the samples with aqueous acetone (70\% acetone). Afterwards, the butanol- $\mathrm{HCl}$ and ferric reagents were added, followed by measuring the absorbance at $550 \mathrm{~nm}$ with a spectrophotometer. CT levels were expressed as g CT kg-1 DM.

The experimental diets were fed daily ad libitum on a pen basis, for 35 days. The daily rations allow for $10 \%$ remaining feed. Fresh drinking water was provided daily ad libitum.

\section{Sampling procedures and analysis}

The live body weights of sheep were taken at commencement of the trial and weekly thereafter. Weighing was done without fasting the animals, but always in the early morning before the daily ration was offered.

Fresh dung samples were collected directly from the rectum of individual sheep for FEC analysis. Samples were collected prior to the start of the experiment to determine the level of GIN infection and then at the commencement of the trial to aid in the randomisation of the animals. Thereafter, collections were made weekly until Day 35, when the experiment was terminated.

Faecal samples $\left(10 \mathrm{~g}\right.$ animal $^{-1}-15 \mathrm{~g}$ animal $\left.^{-1}\right)$ were analysed for FEC using the modified McMaster and Visser slide technique (Hansen \& Perry 1994). Three grams of the collected faeces were diluted in $30 \mathrm{~mL}$ of saturated sugar solution. After mixing, a sample was taken with a pipette and dropped into the McMaster slide chambers. Using a microscope, ova were counted on both sides of the chamber and multiplied by 50 to estimate the total number of eggs in a sample, as EPG of faeces.

Rectal temperature was taken with a handheld thermometer (Digiflash; Pfizer). Rectal temperatures were taken early in the morning, and care was taken that the animals were not exposed to abnormal activities before readings were taken.

FAMACHA $^{\odot}$ scoring is an indirect measurement of the level of anaemia, as observed by the colour of the mucous membrane of the eye, which is assessed using a colour guide chart. A scoring of between 1 and 5 is used, where 1 is healthy, pink-red colour and 5 is white mucous membranes, indicating severe anaemia as a result of parasitism (Van Wyk \& Bath 2002).

Animal weights, FAMACHA $^{\odot}$ scores and rectal temperatures were taken simultaneously with dung sample collection.

\section{Statistical analysis}

The data on live mass of sheep, FEC, FAMACHA ${ }^{\odot}$ and rectal temperatures were analysed using the statistical program Genstat (Payne et al. 2011). Repeated measures analysis of variance was used for the FEC, live mass and rectal temperature, which were measured over time. Log transformations were done on the FEC data to stabilise variance. Fisher's protected test of least significant differences (LSD) was conducted at a 5\% significance level. Multiple regression analysis was used to test for relationships.

\section{Results}

\section{Chemical composition of feed and intake}

The results of the analyses of chemical composition and the CT content of the M. sativa hay, which made up the ration of the $\mathrm{M}$ group, were $16.55 \%$ crude protein (CP), $44.52 \%$ neutral detergent fibre (NDF) and $36.12 \%$ acid detergent fibre (ADF), with the CT content of $<1.5 \mathrm{~g} \mathrm{~kg}^{-1} \mathrm{DM}$. The results for the $\mathrm{L}$ group were $17.17 \% \mathrm{CP}, 41.91 \% \mathrm{NDF}$ and $30.45 \% \mathrm{ADF}$, with the $\mathrm{CT}$ content of $80 \mathrm{~g} \mathrm{~kg}^{-1} \mathrm{DM}$. The results are presented in Table 1. Voluntary intake over the trial period was similar for both groups.

\section{Live weight}

The average live body weight of the sheep at commencement of the trial was $54.90 \mathrm{~kg} \pm 5.78 \mathrm{~kg}$. Ewes in the L group had an average daily gain (ADG) of $0.08 \mathrm{~g} \mathrm{sheep}^{-1} \mathrm{day}^{-1}$, and ewes in the $\mathrm{M}$ group had an ADG of $0.09 \mathrm{~g}$ sheep $^{-1}$ day $^{-1}$. Treatments did not differ significantly $(p>0.05)$, but the interaction

TABLE 1: Crude protein, fibre (neutral detergent fibre and acid detergent fibre) and condensed tannin levels of the rations fed to sheep.

\begin{tabular}{lcc}
\hline Parameter & L group ration & M group ration \\
\hline $\mathrm{CP}(\%)$ & 17.17 & 16.55 \\
$\mathrm{NDF}(\%)$ & 41.91 & 44.52 \\
$\mathrm{ADF}(\%)$ & 30.45 & 36.12 \\
$\mathrm{CT}\left(\mathrm{g} \mathrm{kg}^{-1} \mathrm{DM}\right)$ & 80.00 & $<1.50$ \\
\hline
\end{tabular}

$\mathrm{CP}$, crude protein; NDF, neutral detergent fibre; $A D F$, acid detergent fibre; $C T$, condensed tannins. 
between treatment and time, indicating a live weight increase over time, was significant $(p<0.05)$.

\section{Faecal egg count}

The mean FEC, 3086 EPG for the L group and 3143 EPG for the $\mathrm{M}$ group at the start of the experiment, decreased in both groups following commencement of feeding up to Day 14 (829 EPG for the L group and 1286 EPG for the M group). The FEC then gradually increased in both groups from Day 14 to Day 21, with the levels of 1557 EPG for the L group and 2586 EPG for the $M$ group. A slight decrease on Day 28 and then an increase on Day 35 for the L group were recorded with the final mean FEC of 1643 EPG for the L group and 3329 EPG for the M group. FEC levels in the $M$ group followed the same trend compared to the L group, but at higher levels of FEC (Figure 1).

FEC levels in the two treatments were not significantly $(p>0.05)$ different up to Day 28 but were significantly different by Day $35(p=0.05)$, with high variability in the data. $\log _{\mathrm{e}}$ transformations were used to stabilise the variance in FEC (Table 2). FEC changes over time were highly significant in both treatment groups $(p<0.001)$.

\section{Rectal temperature}

The normal rectal temperature of sheep varies between $38.3^{\circ} \mathrm{C}$ and $39.9{ }^{\circ} \mathrm{C}$. The rectal temperatures of the sheep on trial

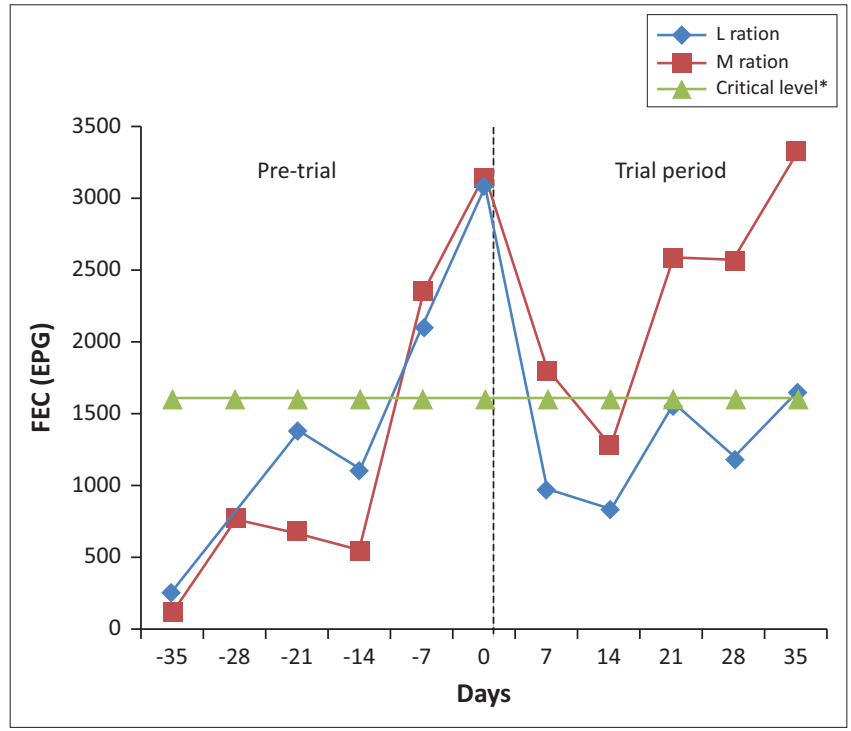

FEC, faecal egg count; EPG, eggs per gram.

FIGURE 1: The effect of feeding a Lespedeza cuneata or Medicago sativa hay ration on the faecal egg count of parasitised sheep in the trial with indication of the critical faecal egg count level according to Colditz 2008.

TABLE 2: The faecal egg count results ( $\log _{e}$ transformations) of sheep on different days on a Lespedeza cuneata or Medicago sativa hay ration.

\begin{tabular}{lccccc}
\hline Days & $\begin{array}{l}\text { FEC (Log transformations) for } \\
\text { sheep fed different rations }\end{array}$ & SEM & $\begin{array}{c}\text { LSD of means } \\
\mathbf{( 5 \%} \text { level) }\end{array}$ & $p$ \\
\cline { 2 - 3 } & Lespedeza & Medicago & & & \\
\hline Day 7 & 6596 & 7130 & 0.37 & 1.15 & $>0.05$ \\
Day 14 & 6316 & 7064 & 0.31 & 0.97 & $>0.05$ \\
Day 21 & 6647 & 7664 & 0.45 & 1.39 & $>0.05$ \\
Day 28 & 6744 & 7608 & 0.36 & 1.10 & $>0.05$ \\
Day 35 & 7139 & 7981 & 0.28 & 0.86 & $=0.05$ \\
\hline
\end{tabular}

FEC, faecal egg count; LSD, least significant difference. were monitored to investigate whether differences could be detected between the rectal temperatures of sheep in the treatment groups with different parasite loads (Figure 2). For the duration of the experiment, the measured rectal temperatures were within the normal range. As temperatures were taken during the cool early morning, air temperatures were not taken into consideration.

The rectal temperature in the $\mathrm{M}$ group was consistently lower for the duration of the experiment compared with the $\mathrm{L}$ group, although the difference was not significant $(p>0.05)$. A decrease in rectal temperature was observed on Day 14 of the experiment, which coincided with a lower level in the FEC. The explanation of this observation is unclear.

The differences in mean rectal temperature between the treatments were not significant at the 5\% level $(p=0.05)$, but there was a trend for lower temperatures on Day 21 $(p<0.07)$ and on Day $28(p<0.08$; Table 3$)$. No significant relationship existed between rectal temperature and FEC over the trial period.

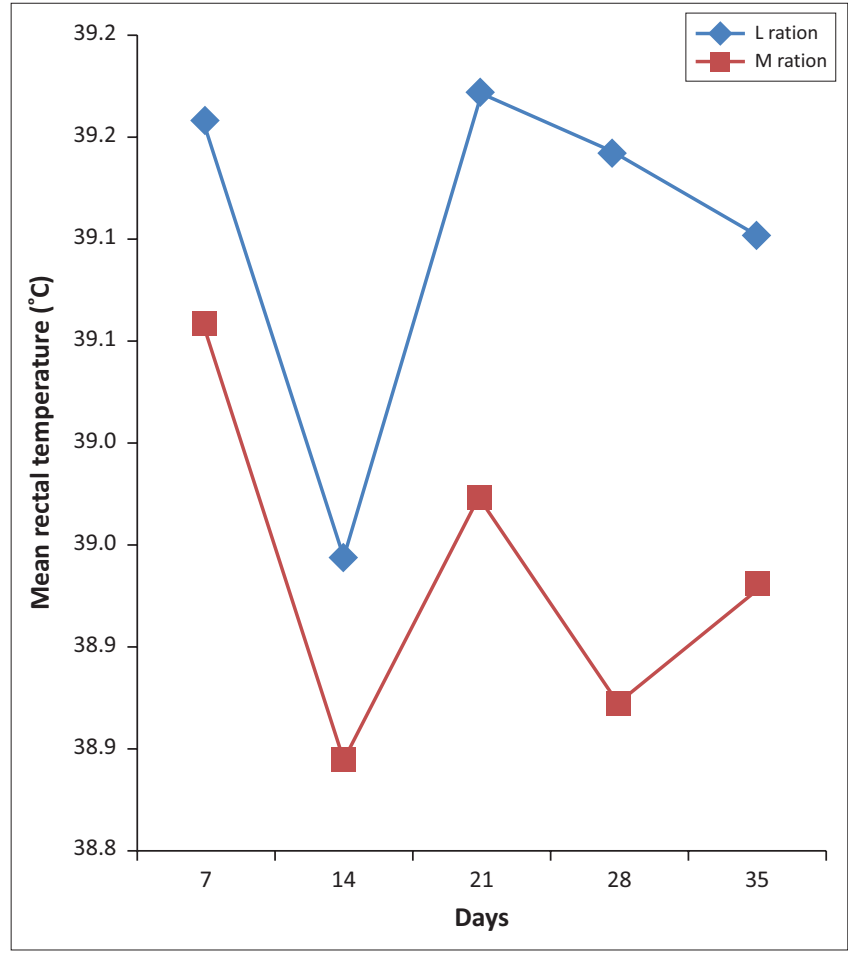

FIGURE 2: The effect of feeding Lespedeza cuneata or Medicago sativa hay on the mean rectal temperature $\left({ }^{\circ} \mathrm{C}\right)$ of parasitised sheep.

TABLE 3: The rectal temperatures $\left({ }^{\circ} \mathrm{C}\right)$ of sheep on a Lespedeza cuneata or Medicago sativa hay ration.

\begin{tabular}{lccccc}
\hline Time & $\begin{array}{l}\text { Rectal temperature }\left({ }^{\circ} \mathbf{C}\right) \text { for } \\
\text { sheep fed different rations }\end{array}$ & $p$ & $\begin{array}{c}\text { LSD of means } \\
\text { (5\% level) }\end{array}$ & SEM \\
\cline { 2 - 3 } & Lespedeza & Medicago & & & \\
\hline Day 7 & 39157 & 39057 & 0.59 & 0.397 & 0.129 \\
Day 14 & 38943 & 38843 & 0.55 & 0.352 & 0.114 \\
Day 21 & 39171 & 38971 & 0.07 & 0.220 & 0.071 \\
Day 28 & 39143 & 38871 & 0.08 & 0.081 & 0.310 \\
Day 35 & 39100 & 38929 & 0.12 & 0.222 & 0.072 \\
\hline
\end{tabular}

LSD, least significant difference. 


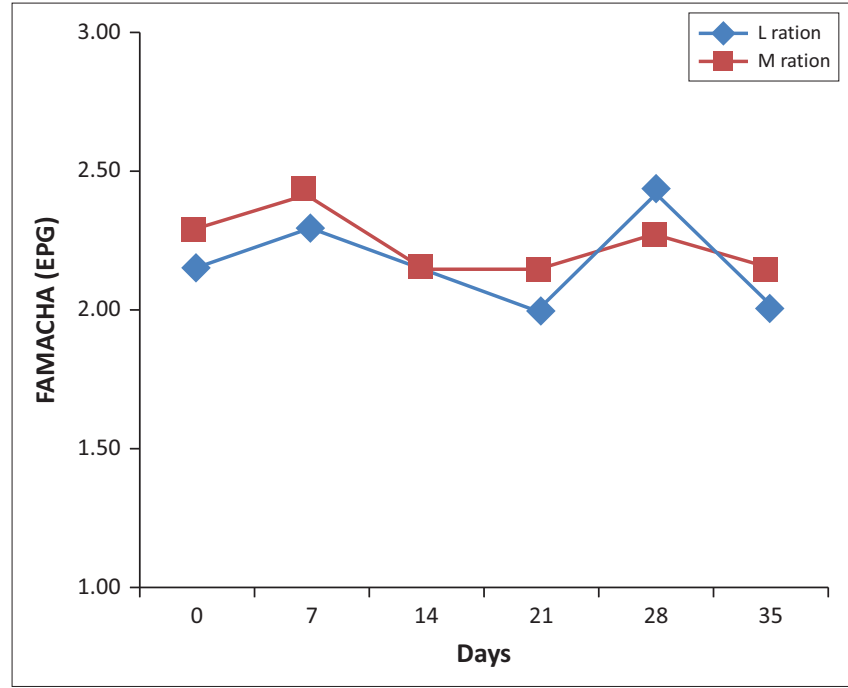

EPG, eggs per gram.

FIGURE 3: The effect of feeding a Lespedeza cuneata or Medicago sativa hay ration on the mean FAMACHA ${ }^{\oplus}$ scores of parasitised sheep.

No significant $(p>0.05)$ differences were detected in the FAMACHA $^{\odot}$ scores. The scores also did not pick up the changes in infection as shown in the FEC results. The low FAMACHA $^{\odot}$ scores indicated that sheep were only slightly anaemic (Figure 3).

\section{Discussion}

Feeding of a Lespedeza leaf hay ration to parasitised sheep appears to be an effective means of suppressing GIN infection in mature Merino sheep. The FEC levels between the treatments in the current investigation decreased by $47 \%$ in the L group compared with an increase of $6 \%$ in the $\mathrm{M}$ group compared with the levels at the commencement of the trial.

The reduction in FEC observed in the L group confirms results from previous studies where L. cuneata, fed in dried form (hay, leaf meal and pellets), resulted in reduced FEC. Lange et al. (2006) investigated the effect of Lespedeza hay on the worm burdens in lambs. The worm burden was reduced by $67 \%$ and the establishment of incoming larvae was reduced by $26 \%$. Shaik et al. (2006) tested L. cuneata hay as a natural deworming agent against GINs in goats and found that FECs were significantly reduced, compared with goats fed Cynodon dactylon hay. Kommuru et al. (2014) reported a decreased FEC within 1 week of feeding a $90 \%$ L. cuneata ration to GIN-infected kids, but Terrill et al. (2007) reported an initial delayed reaction on the effect on egg production when feeding L. cuneata hay to goats in a titration study.

The $\mathrm{L}$ ration in the current study consisted of $80 \%$ Lespedeza leaves. Burke et al. (2011) did a L. cuneata dose titration study on lambs. Lespedeza cuneata meal was fed to H. contortusinfected lambs in diets containing $0 \%, 25 \%, 50 \%$ and $75 \%$ Lespedeza and concluded that FEC was not influenced by the L. cuneata fraction in the diet.
Min and Hart (2003) compared the results of several studies regarding the effects of $\mathrm{CT}$ levels on FEC reduction. When CT levels increased above $55 \mathrm{~g} \mathrm{~kg}^{-1} \mathrm{DM}$ and decreased below $45 \mathrm{~g} \mathrm{~kg}^{-1} \mathrm{DM}$, the FEC responses became variable, but between these levels (45 g $-55 \mathrm{~g}$ of CT kg-1 DM), fairly constant FEC reductions of $\pm 50 \%$, relative to non-CT containing forages, were reported. More specifically, L. cuneata, with CT content of $50 \mathrm{~g} \mathrm{~kg}^{-1} \mathrm{DM}$, had shown to reduce FEC by $60 \%$.

The Lespedeza leaves in the current study had a CT content of $80 \mathrm{~g} \mathrm{~kg}^{-1} \mathrm{DM}$, which exceeds the critical level of $55 \mathrm{~g} \mathrm{~kg}^{-1}$ DM mentioned above, after which FEC response seemed to become variable. However, this level is well within the range of $46 \mathrm{~g} \mathrm{~kg}^{-1}-152 \mathrm{~g} \mathrm{~kg}^{-1}$ DM mentioned by Coffey et al. (2007) as expected levels of CT in L. cuneata. In comparison, these authors reported expected CT levels of $0.5 \mathrm{~g} \mathrm{~kg}^{-1} \mathrm{DM}$ for M. sativa, $48 \mathrm{~g} \mathrm{~kg}^{-1} \mathrm{DM}$ for Birdsfoot trefoil, $77 \mathrm{~g} \mathrm{~kg}^{-1} \mathrm{DM}$ for Big trefoil and $29 \mathrm{~g} \mathrm{~kg}^{-1} \mathrm{DM}$ for sainfoin.

The results of the current study also correspond fairly well with similar experiments conducted by Niezen et al. $(1995,1998)$, where the FEC results of parasitised lambs on Hedysarum coronarium (sulla), a high CT-containing forage (CT of $110 \mathrm{~g} \mathrm{~kg}^{-1} \mathrm{DM}$ ), and on M. sativa, a low CT-containing forage (CT of $\left.1.5 \mathrm{~g} \mathrm{~kg}^{-1} \mathrm{DM}\right)$, were compared. The effect of grazing was significantly different $(p<0.01)$ for FEC; differences of 1320 EPG for $H$. coronarium were recorded, compared with an FEC of 2200 EPG for M. sativa. A total worm burden of 10553 for H. coronarium was measured, compared with 18676 for M. sativa (Min \& Hart 2003).

Several authors reported that the tannins in tannin-rich forages become more polarised when field-dried, resulting in a lower number of free hydroxyls available for binding proteins, which implies that, in hay form, safe intake levels could be higher when compared with green grazing (Barry \& McNabb 1999; Hovarth 1981; Reed, Soller \& Woodward 2003; Terrill et al. 1989). These 'unbound' CTs are most likely the active agent giving the plant its anthelmintic properties. The molecular structure of CT in the plant is more critical to its anthelmintic properties than the concentration of different CT types (Shaik et al. 2006).

GIN, voracious bloodsucking endoparasites living in the digestive tract of their host, creates extensive damage to the gastrointestinal mucosa. This results in increased plasma leakage and losses of endogenous protein, as well as interference with the retention of nitrogen, vitamins and minerals (Kimambo et al. 1988; Villalba et al. 2014). Colditz (2008) reported that a blood loss of $10 \mathrm{~mL} \mathrm{day}^{-1}$ is typical of what parasitised mature sheep with an FEC of 1600 EPG experienced. Blood loss in excess of this norm will result in anaemia. The results in the current study showed that the FEC in the L group were consistently below this norm from Day 7, which was not the case in the $\mathrm{M}$ group. These results suggested that the sheep in the $M$ group would have required anthelmintic treatment at the termination of the 
trial, compared with sheep in the L group where treatment was not required.

The trend of higher rectal temperatures in the $\mathrm{L}$ group, corresponding with the trend in FEC in the two treatments, suggests a possible lower level of anaemia in the L group compared with the M group. However, Specht (1982), after an investigation into the effect of GIN infections on hostbody temperature, concluded that body temperature results did not show as close a relationship to parasite infection as expected.

FAMACHA $^{\odot}$ scoring, a well-known indicator of the level of anaemia in small stock, did not detect any differences between the two treatment groups over the trial period. This lack of anaemia, despite the FEC results, was possibly mediated by improved nutrition as a result of the high protein content of both experimental diets, which replenished the endogenous protein losses encountered during GIN parasitism. This is supported by the work by Van Houtert and Sykes (1996) who showed that host resilience or the ability of the animal to withstand the effects of infection can be markedly enhanced by increasing the metabolisable protein supply, which in the case of the current study was supplied by both forages used in the trial.

The reduced FEC results in the L group could be a direct or indirect effect of the CT on the GIN, either by reduced female parasite egg shedding or reduced numbers of parasites. Both Shaik et al. (2006) and Lange et al. (2006) attributed reduced FEC to lower parasite numbers and a reduction in worm fecundity.

The lasting anthelmintic effects on GIN after cessation of the CT-containing feed appear to be variable. Heckendorn (2007) reported a sustainable reduction in FEC, but other studies showed that reduction in EPG disappeared when CTcontaining feeding was stopped (Coffey et al. 2007; Lange et al. 2006; Min et al. 2004), indicating that worms were inhibited and not killed. Athanasiadou and Kyriazakis (2000) suggested that CT only temporarily reduced female worm fecundity.

Goats and sheep differ in their level of tolerance to the effects of CT. The more protein-rich saliva excreted by goats while eating is thought to be the first defence against tannins, compared with sheep. Goats are generally more tolerant of CT than sheep, hence their browsing habits (Hoste et al. 2007; Min \& Hart 2003; Mueller-Harvey 2006). Therefore, care must be taken to not equate the anthelmintic-related results from goat studies directly to sheep.

\section{Conclusion}

The study proved that by feeding L. cuneata hay to GINinfected sheep, the level of infection, as measured by FEC, decreased substantially. Rectal temperatures and FAMACHA $^{\odot}$ scoring as an indication of anaemia level of GIN infection could not detect the changes in GIN infection. This was most possibly due to the high protein content of the experimental diets, which curbs endogenous protein losses as a result of GIN parasitism. The proven efficacy of L. cuneata hay as an anthelmintic suppressor holds exciting possibilities for sheep farmers. Lespedeza cuneata, as an already established planted pasture with agronomic advantages, such as nitrogen-fixing abilities, relative drought resistance and adaptability to low fertility soils, together with anthelmintic properties, can therefore, be advantageously and flexibly incorporated in the fodder flow programmes on sheep farms. In addition to providing a high protein content forage, L. cuneata can be strategically offered to animals when a GIN challenge is expected, such as when weather becomes favourable for the development of GIN infections. Further, with less GIN egg shedding, pasture contamination will decrease future infections.

\section{Acknowledgements}

This research was supported by KZN Department of Agriculture and Rural Development and the Faculty of Veterinary Sciences, University of Pretoria, South Africa. Appreciation is extended to the Vryheid State Laboratory, KZN Department of Agriculture and Rural Development.

\section{Competing interests}

The authors declare that they have no financial or personal relationships that may have inappropriately influenced them in writing this article.

\section{Authors' contributions}

E.A.v.Z. was the main researcher, planner and executer of the physical field experiments and interpretation of results, and wrote the manuscript. F.S.B. was the supervisor of MSc studies, advised during the experiment and was responsible for interpretation of results and editing the manuscript. K.J.N.E. was the co-supervisor of MSc study, advised during the experiment and was responsible for interpretation of results and editing the manuscript. P.P.M. and P.A.O. supported in technical execution of the trial. C.S. assisted with biometry analysis.

\section{References}

Adamu, M., 2012, 'The efficacy of traditionally used Leucosidea sericea (Rosaceae) against Haemonchus contortus and microbial pathogens', PhD thesis, Department of Paraclinical Sciences, Faculty of Veterinary Science, University of Pretoria, South Africa.

Adamu, M., Naidoo, V. \& Eloff, J.N., 2013, 'Efficacy and toxicity of thirteen plant leaf acetone extractions used in ethnoveterinary medicine in South Africa on egg hatching and larval development of Haemonchus contortus', BMC Veterinary Research 9, 38. https://doi.org/10.1186/1746-6148-9-38

Ahmed, M., Laing, M.D. \& Nsahlai, I.V., 2010, 'In vivo effect of selected medicinal plants against gastrointestinal nematodes of sheep', Tropical Animal Health and Production 46, 411-417. https://doi.org/10.1007/s11250-013-0506-0

Athanasiadou, S., Gray, D., Younie, D., Tzamaloukas, O., Jackson, F. \& Kyriazakis, I., 2007 , 'The use of chicory for parasite control in organic ewes and their lambs', Parasitology 134, 299-307. https://doi.org/10.1017/\$0031182006001363

Athanasiadou, S. \& Kyriazakis, I., 2000, 'Consequences of long-term feeding with condensed tannins on sheep parasitised with Trichostrongylus colubriformis', International Journal for Parasitology 30, 1025-1033. https://doi.org/10.1016/ S0020-7519(00)00083-7

Barry, T.N. \& McNabb, W.C., 1999, 'The implications of condensed tannins on the nutritive value of temperate forages fed to ruminants', The British journal of nutrition 81, 263-272. 
Berger, J., 1975, 'The resistance of a field strain of Haemonchus contortus to five benzimidazole anthelmintics in current use', Journal of South African Veterinary Association 46, 369-372.

Besier, R.B. \& Love, S.C.J., 2003, 'Anthelmintic resistance in sheep nematodes in Australia: The need for new approaches', Australian Journal of Experimental Agriculture 43, 1383-1391. https://doi.org/10.1071/EA02229

Bown, M.D., Poppi, D.P. \& Sykes, A.R., 1991, 'The effect of post-ruminal infusion of protein or energy on the pathophysiology of Trichostrongylus colubriformis infection and body composition in lambs', Australian Journal of Agricultural Research 42, 253-267. https://doi.org/10.1071/AR9910253

Burke, J.M., Whitley, N.C., Pollard, D.A.J., Miller, J.E., Terrill, T.H. \& Moulton, K.E., 2011, 'Dose titration of sericea lespedeza leaf meal on Haemonchus contortus infection in lambs and kids', Veterinary Parasitology 181, 345-349. https://doi. org/10.1016/j.vetpar.2011.05.005

Coffey, L., Hale, M., Terrill, T., Mosjidis, J. \& Miller J.B., 2007, Tools for managing internal parasites in small ruminants: Sericea Lespedeza, ATTRA-National Sustainable Agriculture Information Service, Butte, MT, pp. 1-8.

Colditz, I.G., 2008, 'Challenges to the development of new tests for diagnosis of infection and prediction of resistance of sheep to gastrointestinal nematodes', Tropical Biomedicine 25, 41-49.

Dannhauser, C.D. (ed.), 2002, Fodder legumes in the summer rainfall areas of southern Africa, Sansor, Pretoria, South Africa.

De Figueiredo, M. \& Thurtell, L., 1998, Analytical methods and instruments used in the Cedara Feed Laboratory, Cedara Agricultural Institute, Department of Agriculture, Pietermaritzburg, South Africa.

Foster, J.G., Cassida, K.A. \& Turner, K.E., 2011, 'In vitro analysis of the anthelmintic activity of forage chicory (Cichorium intybus $L$.) sesquiterpene lactones against a predominantly Haemonchus contortus egg population', Veterinary Parasitology 180, 298-306. https://doi.org/10.1016/j.vetpar.2011.03.013

Greef, J.C., Karrison, L.J.E. \& Schlink, A.C., 2014, 'Breeding productive low cost Merino sheep', viewed 10 September 2014, from http://www.merino2014.com

Gujja, S., Terrill, T.H., Mosjidis, J.A., Miller, J.E., Mechineni, A. \& Kommuru, D.S., 2013 'Effect of supplemental sericea lespedeza leaf meal pellets on gastrointestinal nematode infection in grazing goats', Veterinary Parasitology 191, 51-55. https:// doi.org/10.1016/j.vetpar.2012.08.013

Hansen, J. \& Perry, B., 1994, The epidemiology, diagnosis and control of helminth parasites of ruminants, International Laboratory for Research on Animal Diseases, Nairobi, Kenya.

Heckendorn, F., 2007, 'The control of gastrointestinal sheep nematodes with tanniferous forage plants', Dissertation for the degree, Doctor of Science, Swiss Federal Institute of Technology, Zurich.

Hoste, H., Heckendorn, F., Werne, S. \& Sotiraki, S., 2014, Sainfoin, a natural anthelmintic for livestock, LowlnputBreeds, Technical note, viewed 23 November 2015, from http://www.lowinputbreeds.org

Hoste, H., Jackson, F., Athanasiadou, S., Thamsborg, S.M. \& Hoskin, S.O., 2006, 'The effects of tannin-rich plants on parasitic nematodes in ruminants', Trends in Parasitology 22, 253-261. https://doi.org/10.1016/j.pt.2006.04.004

Hoste, H., Torres-Acosta, J.F.J. \& Aguilar-Caballero, A.J., 2007, 'Nutrition-parasite interactions in goats: Is immunoregulation involved in the control of gastrointestinal nematodes?', Parasite Immunology 30, 79-88.

Hovarth, P.J., 1981, 'The nutritional and ecological significance of Acer-tannins and related polyphenols', MS thesis, Cornell University, Ithaca, NY.

Kimambo, A.E., MacRae, J.C., Walker, A., Watt, C.F. \& Loop, R.L., 1988, 'Effect of prolonged subclinical infection with Trichostrongylus colubriformis on the performance and nitrogen metabolism of growing lambs', Veterinary Parasitology 28, 191-203. https://doi.org/10.1016/0304-4017(88)90107-0

Kommuru, D.S., Barker, T., Desai, S., Burke, J.M., Ramsay, A., Mueller-Harvey, I. et al., 2014, 'Use of pelleted sericea lespedeza (Lespedeza cuneata) for natural control of coccidia and gastrointestinal nematodes in weaned goats', Veterinary Parasitology 204, 191-198. https://doi.org/10.1016/j. vetpar.2014.04.017

Lange, K.C., Olcott, D.D., Miller, J.E., Mosjidis, J.A., Terrill, T.H. \& Burke, J.M., 2006 'Effect of sericea lespedeza (Lespedeza cuneata) fed as hay, on natural and experimental Haemonchus contortus infections in lambs', Veterinary Parasitology 141, 273-278. https://doi.org/10.1016/j.vetpar.2006.06.001

Min, B.R. \& Hart, S.P., 2003, 'Tannins for suppression of internal parasites', Journal of Animal Science 81, 102-109.

Min, B.R., Hart, S.P., Miller, D., Tomita, G.M., Loetz, E. \& Sahlu, T., 2005, 'The effect of grazing forage containing condensed tannins on gastro-intestinal parasite infection and milk composition in Angora goats', Veterinary Parasitology 130 105-113. https://doi.org/10.1016/j.vetpar.2005.03.011

Min, B.R., Pomroy, W.E., Hart, S.P. \& Sahlu, T., 2004, 'The effect of short-term consumption of a forage containing condensed tannins on gastro-intestinal nematode parasite infections in grazing wether goats', Small Ruminant Research 51, 279-283. https://doi.org/10.1016/S0921-4488(03)00204-9

Moore, D.A., Terrill, T.H. Kouakou, B, Shaik, S.A., Mosjidis, J.A., Miller, J.E. et al, 2008 'The effects of feeding sericea lespedeza hay on growth rate of goats naturally infected with gastrointestinal nematodes', Journal of Animal Science 86(9), 2328-2337. https://doi.org/10.2527/jas.2007-0411

Morgan, E., Charlier, J., Hendrick, G., Biggeri, A., Catalan, D. \& Von SamsonHimmelstjerna, G., 2013, 'Global change and helminth infections in grazing ruminants in Europe: Impacts, trends and sustainable solutions', Agriculture 3 484-502. https://doi.org/10.3390/agriculture3030484
Mueller-Harvey, I., 2006, 'Unravelling the conundrum of tannins in animal nutrition and health', Journal of the Science of Food and Agriculture 86, 2010-2037. https:// doi.org/10.1002/jsfa.2577

Niezen, J.H., Charleston, W.A., Robertson, H.A., Shelton, D., Waghorn, G.C. \& Green, R., 2002, 'The effect of feeding sulla (Hedysarum coronarium) or lucerne (Medicago sativa) on lamb parasite burdens and development of immunity to gastrointestinal nematodes', Veterinary Parasitology 105, 229-245. https://doi. org/10.1016/S0304-4017(02)00014-6

Niezen, J.H., Robertson, H.A., Waghorn, G.C. \& Charleston, W G., 1998, 'Production, faecal egg counts and worm burdens of ewe lambs which grazed six contrasting forages', Veterinary Parasitology 80, 15-27. https://doi.org/10.1016/S03044017(98)00202-7

Niezen, J.H., Waghorn, T.S., Charleston, W.A. \& Waghorn, G.C., 1995, 'Growth and gastrointestinal parasitism in lambs grazing one of seven herbages and dosed with larvae for six weeks', Journal of Agricultural Sciences 125, 281-289. https://doi. org/10.1017/S0021859600084422

Payne, R.W., Murray, D.A., Harding S.A., Baird, D.B. \& Soutar, D.M., 2011, An introduction to GenStat for windows, 14th edn., VSN International, Hemel Hempstead, United Kingdom.

Preston, J.S.M., Sandeman, M., Gonzales, J. \& Piedrafita, D., 2014, 'Current status for gastrointestinal nematode diagnosis in small ruminants: Where are we and where are we going?', Journal of Immunology Research 2014, 12. https://doi. org/10.1155/2014/210350

Rahmann, G. \& Seip, H., 2007, 'Bioactive forage and phytotherapy to cure and control endo-parasite diseases in sheep and goat farming systems - A review of current scientific knowledge' [Bioactive forage and phytotherapy to cure and control endo-parasite diseases in sheep and goat farming systems - a review of current scientific knowledge.], Landbauforschung Völkenrode, pp. 285-295, Bundesforschungsanstalt für Landwirtschaft, Westerau, Germany.

Reed, J.D., McDowell, R.T.E., Van Soest, P.J. \& Horvath, P.R.J., 1982, 'Condensed tannins: A factor limiting the use of cassava forage', Journal of the Science of Food and Agriculture 33, 213-220. https://doi.org/10.1002/jsfa.2740330302

Reed, J.D., Soller, H. \& Woodward, A., 2003, 'Fodder tree and straw diets for sheep: Intake, growth, digestibility and the effects of phenolics on nitrogen utilisation' Animal Feed Science and Technology 30(1-2), 39-50.

Shaik, S.A., Terrill, T.H., Miller, J.E., Kouakou, B., Kannan, G., Kallu, R.K. et al., 2004 'Effects of feeding sericea lespedeza hay to goats infected with Haemonchus contortus', South African Journal of Animal Science 34, 248-250.

Shaik, S.A., Terrill, T.H., Miller, J.E., Kouakou, B., Kannan, G. \& Kaplan, R.M., 2006, 'Sericea lespedeza hay as a natural deworming agent against gastrointestinal nematode infection in goats', Veterinary Parasitology 139, 150-157. https://doi. org/10.1016/j.vetpar.2006.02.020

Shimada, T., 2006, 'Salivary proteins as a defense against dietary tannins', Journal of Chemical Ecology 32, 1149-1163. https://doi.org/10.1007/s10886-006-9077-0

Specht, E.J., 1982, 'Seasonal incidence of helminths in sheep and goats in south Mozambique', Veterinary Parasitology 11, 317-328. https://doi.org/10.1016/ 0304-4017(82)90100-5

Taylor, M.A., Hunt, K.R. \& Goodyear, K.L., 2002, 'Anthelmintic resistance detection methods', Veterinary Parasitology 103, 183-194. https://doi.org/10.1016/S0304 4017(01)00604-5

Terrill, T.H., Mosjidis, J.A., Moore, D.A., Shaik, S.A., Miller, J.E. \& Burke, J.M., 2007, 'Effect of pelleting on efficacy of sericea lespedeza hay as a natural dewormer in goats', Veterinary Parasitology 146, 117-122. https://doi.org/10.1016/j. vetpar.2007.02.005

Terrill, T.H., Windham, W.R., Hoveland, C.S. \& Amos, H.E., 1989, IInfluence of forage preservation method on tannin concentration, intake and digestibility of sericea lespedeza by sheep', Agronomy Journal 81, 435-439. https://doi.org/10.2134/agr onj1989.00021962008100030007x

Valderrábano, J., Calvete, C. \& Uriarte, J., 2010, 'Effect of feeding bioactive forages on infection and subsequent development of Haemonchus contortus in lamb faeces',
Veterinary Parasitology 172, 89-94. https://doi.org/10.1016/j.vetpar.2010.04.018

Van Houtert, M.J.F. \& Sykes, A.R., 1996, 'Implication of nutrition for the ability of ruminants to withstand gastrointestinal nematode infections', International Journal for Parasitology 26(11) 1151-1168. https://doi.org/10.1016/s0020 7519(96)00120-8

Van Soest, P.J., 1965, 'Symposium on factors influencing the voluntary intake of herbage by ruminants: Voluntary intake in relation to chemical composition and digestibility', Journal of Animal Science 24, 834. https://doi.org/10.2527/ jas1965.243834x

Van Wyk, J.A. \& Bath, G.F., 2002, 'The Famacha system for managing haemonchosis in sheep and goats by clinically identifying individual animals for treatment' Veterinary Research 33(5), 509-529. https://doi.org/10.1051/vetres:2002036

Van Wyk, J.A., Stenson, M.O., Van der Merwe, J.S., Vorster, R.J. \& Viljoen, P.G., 1999, 'Anthelmintic resistance in South Africa: Surveys indicate an extremely serious situation in sheep and goat farming', Onderstepoort Journal of Veterinary Research 66, 273-284.

Vatta, A.F. \& Lindberg, A.L.E., 2006, 'Managing anthelmintic resistance in small ruminant livestock of resource-poor farmers in South Africa', Journal of South African Veterinary Association 77(1), 2-8. https://doi.org/10.4102/jsava. v77i1.331

Villalba, J.J., Miller, J., Ungar, E.D., Landau, S.Y. \& Glendinning, J., 2014, 'Ruminant selfmedication against gastrointestinal nematodes: Evidence, mechanism, and origins', Parasite 21, 31. https://doi.org/10.1051/parasite/2014032

Waterman, P.G. \& Mole, S., 1994, Analysis of phenolic metabolites, Blackwell Scientific Publications, Oxford, UK. 